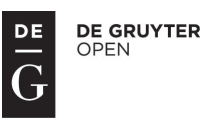

\title{
The World Court of Human Rights FEASIBILITY STUDY
}

\author{
Lubica Saktorová ${ }^{1}$
}

\begin{abstract}
The idea of the World Court of Human Rights was first envisioned in 1947 along with other institutions designed to create a system capable of the worldwide protection of individual human rights. The focus of the present study is to determine key issues of the prospective establishment of the World Court by an examination of its theoretical position among the United Nations bodies, regional and another inter-governmental human rights organisation. Analysis of the function and mechanisms of the current international human rights protection system would lead to deliberation on the prospective substantial and procedural competences of the World Court, the enforcement mechanism, jurisdiction and related benefits. The objective of the final part is to discuss challenges regarding its political and legal feasibility. Without the visionaries of the past, there would be no substantial system of human rights today. The World Court of Human Rights is a vision for the future.
\end{abstract}

\section{Keywords}

International Human Rights Law, Protection, Judicial System, Feasibility, World Court

\section{Introduction}

The idea of the World Court of Human Rights was first envisioned in 1947 along with other institutions designed to create a system that would be capable of the efficient, worldwide protection of human rights. While the other instruments of this brave concept came into existence, there have not been such initiatives to put forward what was probably the bravest. The notion of the establishment of the World Court of Human Rights was reintroduced in 2008 on the occasion of 60th anniversary of the Universal Declaration of Human Rights by the International Panel assembled by the Swiss Government. This proposal became a part of the future Agenda of Human Rights to institute the World Court alongside the United Nations Human Rights Council. ${ }^{2}$ Almost seven decades ago,

\footnotetext{
${ }^{1}$ Law Faculty, University of Matej Bel, Komenského 20, Banská Bystrica, 974 01, Slovakia. E-mail: lubica.saktorova@umb.sk.

${ }^{2} \mathrm{~A} / 65 / 258$ (2010) 'Report of the Special Rapporteur on the promotion and protection of human rights and fundamental freedoms while countering terrorism'.
} 
the United Nations demarcated the framework of a system able to provide people with guarantees of peace, security, and human rights: universal, indivisible, interdependent, and interrelated. ${ }^{3}$ During this time, this framework was gradually developed and filled out according to the needs of society. Indeed, due to the dynamic political situation, new trends and natural evolution, there are still gaps appearing in the system: International Courts, UN organs and treaty bodies, international and regional organisation work well in their particularly designed ways and fields of authorities, but they already lack the ability to cover the whole picture. The World Court of Human Rights would most probably stand on top of the hierarchy representing honoured authority, consistency and the main pillar of the current system of human rights. However, to move from an utopistic to relatively realisable concept to establish such an entity, it is indispensable to examine different approaches to its feasibility and efficiency, the exact scope of its authority, relationship to the other relevant institutions, the enforcement mechanisms, and further theoretical and practical basis of its establishment.

The focus of this study is to determine the key issues of the prospective institution of the World Court of Human Rights, firstly by an examination of its theoretical position among the United Nations (UN) bodies, regional and another inter-governmental organisation. The overview of the function and mechanisms of the human rights institutions will outline the gaps in the system; consequently, it will indicate the urgency and the necessity for the World Court. The second part will be aimed at enquiry into the prospective substantial and procedural competences of the court, the enforcement mechanism, jurisdiction, and related benefits. The objective of the third part will be to consider potential challenges, to discuss the criticism and concerns of the international community regarding current political convenience.

\section{The UN organs, regional and international bodies versus the World Court of Human Rights}

Examination of the feasibility of the establishment of the World Court of Human Rights must be initially drawn upon the current institutional arrangement of bodies assuring the supervision of implementation, protection, promotion, enforcement, and other international and regional safeguard mechanisms of human rights standards. The judicial functions are at the international level represented by the International Court of Justice (ICJ), International Criminal Court (ICC), Permanent Court of Arbitration (PCA) and the Ad Hoc Tribunals based on the Security Council resolutions under Chapter VII of the UN Charter. ${ }^{4}$ At the regional level, there is the European Court of Human Rights (ECtHR), European Court of Justice (ECJ), Inter-American Court of Human Rights (IACtHR) and African Court of Human and People's Rights (ACtHPR); there is no such entity for the Asian and Pacific regions. Furthermore, the UN treaty-based bodies constitute the quasi-judicial organs considering reports from the State parties and occasionally pronounce on individual petitions without legally binding conclusions.

\footnotetext{
${ }^{3}$ Article 5 Vienna Declaration and Program of Action (1993) A/CONF157/23.

${ }^{4}$ S/RES/827 (1993); S/RES/955 (1994).
} 
Firstly, the international jurisdiction operates in restricted fields: advisory opinions, contentious cases, peaceful settlement of disputes, and criminal justice. It is solely the ICC and Ad Hoc Tribunals that concede individual responsibility for the violations of the international criminal and humanitarian law. The past experiences of the failure and difficulties in punishing perpetrators of mass atrocities led to consistent effort to create the permanent International Criminal Court to effectively face current and potential future conflicts. ${ }^{5}$ The violations of the international human rights law did not yet trigger the adoption of concrete measures to create the permanent World Court, despite the fact that these violations should be similarly considered systematic and widespread (Roht and Arriaza, 1995; Edelenbos, 1994). The ratione personae of ICJ is limited to the State parties ${ }^{6}$, although the international human rights are considered through the advisory opinions and the interim measures, they have never been given primacy in ICJ considerations (Tomuschat, 2003, Ušiak and Saktorová, 2014). As the PCA subordinates the admissibility of the case to the mutual consent of the parties, the process of individual complaints is consequently complicated (Hudson, 1933). Hence, the international judicial system does not sufficiently cover the ratione personae (ICJ), direct ratione materiae and the ratione loci (ICC, Ad Hoc Tribunals) with regard to international human rights law.

Secondly, the regional judiciary dealing with the human rights obligations is represented on the African, American and European continents. Their jurisdictions comply with the individual petitions ${ }^{7}$ and relatively functional enforcement mechanisms (Cassel, 2001). Currently, the inflammatory political situation in Africa occupies the world with released information about the enormous infringement of human rights, mostly by the leaders, and the governments (Mubangizi, 2006). The youngest African Court is criticised probably the most: lack of authority, lack of resources, bureaucratic procedures and mostly, very little political will lead to a state of inefficiency and stagnation, whereby it takes years to resolve disputably simple cases (Wachira, 2008). A similar problem of a lack of cooperation and bureaucratic practices delays the work of the American Court: the jurisdiction of IACtHR is limited and depends on the state's ratification of the American Convention of Human Rights, acceptance of its optional/ contentious jurisdiction (Rescia and Seitles, 1999-2000). The individual petition mechanism operates on two levels, forasmuch as after the defendant exhausts all domestic remedies ${ }^{8}$, the case must be presented first before the Commission, whose final report does not possess judicial characteristics. ${ }^{9}$ Legal judgement is reached only after the Court again reviews the case, which often leads to delays, miscommunication, and mostly to a loss of credibility. Probably the best functioning system is the European one, although there is an opposite and most concerning problem of a dramatically increasing caseload (Treschel, 2004). ECtHR successfully provides the honoured system of subordination and respect to international human rights law by the inter-state cases and individual petitions (O'Boyle, 2008). However, the regional human

\footnotetext{
${ }^{5}$ Preamble of Rome Statute; GA/RES/44/89 (1989); GA/RES/50/46 (1995).

${ }^{6}$ Article 34.1 ICJ Statute.

${ }^{7}$ Article 34 ECHR,Article 5(3) Protocol to ACHPR,Article 44 ACHR.

${ }^{8}$ Article 46.1a. ACHR.

${ }^{9}$ Article 51 ACHR.
} 
rights judiciary lacks an effective system for the protection of one's rights, Asia and the Pacific lack a system of protection of individual's rights at all, and the European justice system is highly overloaded.

Thirdly, the frame of human rights protection arises accordingly from nine human rights treaty bodies and the Subcommittee on Prevention of Torture constructing the system to monitor the implementation of the core international human rights treaties by States parties. ${ }^{10}$ Moreover, some bodies work additionally within the inquiry procedure ${ }^{11}$ and examine individual ${ }^{12}$ and inter-state complaints ${ }^{13}$. Although the treaty bodies have established the impressive foundation of international human rights law substantially, the real procedural mechanisms are still lacking in effectiveness. ${ }^{14}$ The creation of the Human Rights Council in 2006, as a main political entity in the field of human rights reforms, became a point of criticism due to its selectivity in addressing the resolutions and nonsupport of the UN human rights system. ${ }^{15}$ Inter-state complaints have never been used; the State's reports are, despite the initiatives of reform, very often delayed. ${ }^{16}$ Even though they generate some pressure on governments to implement the obligations arising from conventions, progress still depends on the State's discretion and willingness to cope (O'Flaherty and O'Brien, 2007, Holubová, 2011) Certainly, it takes time to adjust the legislature, but the long-term ruptures between the national and international rules, unable to be unified and to be effectively enforced, consequently undermine the whole meaning of international human rights protection. The individual petition mechanism is available solely through five treaty bodies; by ratification, States frequently do not accept the optional procedure and make reservations on the individual complaints. (Bayefsky, 1996) Moreover, due to the lack of enforcement mechanism, the States are not always willing to comply with the concluding findings of treaty-based bodies, nor provide satisfactory remedies for the

\footnotetext{
${ }^{10}$ The Human Rights Committee (CCPR): International Covenant on Civil and Political Rights (1966) and its optional protocols; The Committee on Economic, Social and Cultural Rights (CESCR): International Covenant on Economic, Social and Cultural Rights (1966); The Committee on the Elimination of Racial Discrimination (CERD) :International Convention on the Elimination of All Forms of Racial Discrimination (1965); The Committee on the Elimination of Discrimination Against Women (CEDAW): Convention on the Elimination of All Forms of Discrimination against Women (1979) and its optional protocol (1999); The Committee Against Torture (CAT): Convention against Torture and Other Cruel, Inhuman or Degrading Treatment (1984); The Committee on the Rights of the Child (CRC): Convention on the Rights of the Child (1989) and its optional protocols (2000); The Committee on Migrant Workers (CMW): International Convention on the Protection of the Rights of All Migrant Workers and Members of Their Families (1990); The Committee on the Right of Persons with Disabilities (CRPD): International Convention on the Rights of Persons with Disabilities (2006); The Committee on Enforced Disappearance (CED): International Convention for the Protection of All Persons from Enforced Disappearance (2006).

${ }^{11}$ Article 20 CAT; Article 8-10 Opt. Prot. CEDAW.

12 1st Opt. Prot. CCPR; Opt. Prot. CERD; Article 22 CAT; Article 14 CEDAW; Opt. Prot. CPRD.

${ }^{13}$ Articles 21 CAT; 74 CMW; 11-13 ICERD; 41-43 ICCPR.

${ }^{14}$ Report of Proceedings 'Improving Implementation and Follow-up Treaty Bodies, Special Procedures, Universal Periodic Review' (2010) Retrieved May 1, 2016, from http://upr-epu.com/medias/Geneva_Report_of_Proceedings_FINAL.pdf.

15 'Eleanor's Dream' 1948 to 2008: The State of Human Rights at the United Nations. Scorecard and Report on the UN Human Rights Council (2008). Retrieved May 1, 2016, from https://www.scribd.com/document/22193732/Eleanors-Dream-The-State-of-Human-Rights-at-the-United-Nations-1948-to-2008.

16 'Treaty bodies' lists of issues prior to reporting (targeted/focused reports)' HRI/ICM/2010/3.
} 
victims of violations (Goldston, 2011). Thus, although the UN treaty system substantially covers the requirements of the international community, it is a political entity that cannot carry out the functions that have for centuries been fulfilled by an independent judiciary. Analysis of the function of the international, inter-governmental, and regional bodies traces out their essential deficiencies. The fragmentation complicates the concept of unified, international human rights standards accessible and enforceable for those that are primarily addressed. The individual is a cardinal subject of human rights law and despite the successes of the system, on the everyday level very little truly guarantees these rights. The World Court of Human Rights would have a statutory unique position. Accordingly, it would be likely to find a desirable place in the current institutional arrangement.

\section{Justifications for the establishment of the World Court of Human Rights}

While the current system restricts the number of legal procedural tools, essential progress in the establishment of the World Court of Human Rights would to create a platform for individuals to claim their human rights, to have a fair trial according to Universal Declaration and to bring justice back into their lives.

Firstly, after many decades of developing the substance of the international human rights law, the creation of the World Court of Human Rights would represent the willingness of the international community to give those rights real, enforceable value. The Vienna Conference on Human Rights in 1993 reunited the States in affirmation of the universality of human rights ${ }^{17}$, and later on the 2005 World Summit declared human rights to be one of the pillars of the United Nations and the foundations for collective security and well-being. ${ }^{18}$ The core of rule of law lays in the relationship of a 'duty bearer' and a 'right holder', obligations versus rights (Nowak, 2009). Breach of this relationship in all fields of law installs consequences in the form of remedy or punishment. The same should be applicable for human rights law. 'Everyone is entitled in full equality to a fair and public hearing by an independent and impartial tribunal in the determination of his rights and obligations' claims Article 10 of the Universal Declaration of Human Rights. In Article 14.1 of the ICCPR, it is stated that '.. In the determination of any criminal charge against him, or of his rights and obligations in a suit at law, everyone shall be entitled to a fair and public hearing by a competent, independent and impartial tribunal established by law...' The World Court would represent the international authority, the guarantee of universal compliance and accomplishment of these rules. ${ }^{19}$

Secondly, the procedural singularities of the World Court are positive justifications protecting the interests of States. They involve the principle of complementarity within State's jurisdictions and accountability for non-state actors. As a pattern for the establishment of the World Court in various procedural ways may serve the ICC's Rome Statute: special State Conference for drafting and adopting the Statute of the Court will secure judicial

\footnotetext{
${ }^{17}$ Ibid (n3) Article 1.

${ }^{18}$ GA Res. 60/1 World Summit Outcome para. 9.

${ }^{19}$ Articles 7, 26 ACHPR; Article 8 ACHR; Article 47 ECHR.
} 
and institutional independence from other international institutions. ${ }^{20}$ The principle of complementarity will safeguard the State's sovereignty and strengthen the domestic jurisdictions (Nowak and Kozma, 2009). The case would be admissible before the Would Court only under conditions of the unwillingness or inability of State Parties to act. ${ }^{21}$ In addition, the arrangement of a Trust Fund provided by the ICC can disputably serve a similar purpose in the World Court by compensating victims of human rights abuses. ${ }^{22}$ The novelty in a form of accountability for the non-state actors would be the indispensable feature of the new Court (Scheinin, 2009). The international human rights law set up the obligations and duties towards the individuals not only for the State Parties, but accordingly for inter-governmental organisations such as the World Health Organisation, NATO, World Bank, non-governmental organisations, regional entities, or transnational corporations. The responsibility for the abuses of human rights expands the scale beyond the State's power, consequently there should exist the mechanism to proceed.

Thirdly, the World Court would strengthen the operation of the UN treaty bodies, the UN organs, and regional courts. The Human Rights Council would be provided with an independent judicial counterpart, capable of giving legally-binding force to decisions on human rights abuses and vice versa, the Council would supervise the executions of such judgements (Nowak, 2007). The Office of High Commissioner of Human Rights might be strengthened by the ability to request the authoritative opinions of Court on any human rights complaint, a violation, or a legal question on an interpretation of the international human rights norms (Scheinin, 2009). Moreover, the High Commissioner would have additional power to supervise the execution of the judgements of the World Court. In case of the failure of the State Party to enforce such judgement, she might initiate the notification towards the Human Rights Council or the UN Security Council in order to proceed with further actions. Article 46 of European Convention on Human Rights and its Protocol No. 11 provide the functional bases of supervision over the execution of judgements of ECtHR by the Committee of Ministers. The Human Rights Council, as an executive counterpart, will thus reduce the pressure on the Court in order to maintain its credibility and effectiveness. Nonetheless, the beneficiary elements for the regional systems might be recognised through the reduction of the backlog of abuses, reporting procedures and nonetheless, the decreasing caseload of individual applications. In 2010, the caseload of the ECtHR reached its highest number, which was presumably caused by the entry into force of Protocol 14 in June 2010. ${ }^{23}$ According to the Annual Report on Supervision of Execution of Judgements, the most striking element of the Committee of Ministers is the rise in pending cases and the consequent backlog before the Court and the Committee. ${ }^{24}$ The European community might benefit from the establishment of the World

\footnotetext{
${ }^{20} \mathrm{~A} / \mathrm{CONF} 183 / 10$.

${ }^{21}$ Article 17 Rome Statute.

${ }^{22}$ Ibid. Article 79; The Rules of Procedure and Evidence Doc. ICC-ASP/1/3 (2002) Rule 98; 'The International Criminal Court's Trust Fund for Victims' Analysis and Options for the Development of Further Criteria for the Operation of the Trust Fund for Victims (2003) Retrieved May 5, 2016, from http://www.redress.org/downloads/publications/TFVReport.pdf.

23 'Supervision of Execution of Judgements of European Court of Human Rights' 4th Annual Report 2010.

${ }^{24}$ Ibid.
} 
Court by the high probability of it finding release from the current concerning situation. Similarly, the World Court may provide additional support for Ad Hoc Tribunals where necessary and required. ${ }^{25}$ The World Court would strengthen the status of human rights law in the current geo-political landscape specifically in countries without regional human rights protecting mechanisms. Its jurisdiction would have a direct scope of authority on the Asian and Pacific States, which would indeed, ratify the Statute, respecting the principle of complementarity.

Fourthly, the establishment of the World Court of Human Rights would become a major step on a real individual level of increasing public awareness of the possibilities to protect human rights. ${ }^{26}$ Thereafter, it is more likely to generate pressure on the media, admass or civil society to promote the system of human rights protection. The criticised fragmentation of bodies and the complicated procedures deter most individuals from claiming their rights and consequently puts a lot of power into the hands of the actual violators. The unified body of substantial and procedural rules would establish a consistent mechanism that would give the people a particular direction in which they need to proceed for justice. The judgements of the World Court would largely contribute to the system of human rights by the valuable precedents and case law, similarly as the case law of the ECtHR increasingly influences the jurisprudence of nations even outside Europe. ${ }^{27}$

The World Court of Human Rights would represent a contribution to the current system by filling the gaps in procedural rules on international human rights. It would ensure the universal compliance, accomplishment, and interpretation of the substantial norms, it would ensure the accountability of States, but also non-state actors, thus the establishment of the World Court would aim to end impunity for the range of violators of international human rights law. Furthermore, this entity would be more likely to end with tendencies towards unification in the human rights institutional system and strengthen the activities of the other UN, regional, inter-governmental, and international bodies. Individual access to justice might become more clear and effective and the international community will once and forever prove there is no indecision when it comes to enforcing international human rights law.

\section{Challenges and justifications against the establishment of the World Court of Human Rights}

The creation of the one permanent world institution with jurisdiction over international human right law is a concept that requires detailed considerations of the benefits, but also the challenges and potential difficulties. To move from idealistic assumptions to real progress, several issues particularly need to be considered.

\footnotetext{
${ }^{25}$ The Prosecutor v. Callixte Nzabonimana ICTR-98-44D-T 'Decision on Report Of Amicus Curiae on Investigations Related to the Disclosure of Prosecution Witnesses CNAL and CNAE Statements' 14.

26 'Concept Paper on the High Commissioner's Proposal for a Unified Standing Treaty Body' HRI/MC/2006/2 (2006) p. 21.

${ }^{27}$ Lawrence v Texas (2003) 539 U.S. 123 S.Ct. 2472, 2483 (citing decisions of ECtHR as evidence of emerging international rights for homosexuals, to demonstrate that the 'values we share with a wider civilization' now support the 'right of homosexual adults ... as an integral part of human freedom').
} 
Firstly, to create an effective body, the international community and subjects of international law must express their will to comply with the World Court Statute. While certain features of establishment and proceeding are assumed to be set up on similar grounds as the International Criminal Court, criticism might point to a lack of cooperation and willingness on the side of the most influential States and non-state actors in the current geo-political landscape. The US refused to ratify the Rome Statute and it is most likely that it would refuse to ratify the Statute of the World Court. The reasons were predominantly the lack of support and the lack of trust in international bodies; additionally, US officials argued that the best way to combat violations is to build domestic judicial systems, strengthen political will, and promote human freedom. ${ }^{28}$ Moreover, the states might argue the World Court Statute represents a threat to their sovereignty and, although the principle of complementarity provides certain restraints, the authority of the Court might be politically misused. ${ }^{29}$

Secondly, the perception of human rights is diverse in terms of different nations, cultures, religions, political ideologies and moral values (Steiner and others, 2007) Their unification even on a non-binding level is a slow process of mutual dialogue between state and civil representatives. The biggest concern of the advocates of the universality of human rights refer to the cluster of rights that will hardly be accepted by the 'non-western world', such as rights to religious freedom, gender equality or non-discrimination (Donnelly, 2007). The developed countries, for instance, the United Kingdom, only recently incorporated these and similar norms into their own legal orders. ${ }^{30}$ Domestication is a complicated, longrunning procedure and despite the review mechanisms of the monitoring bodies, countries are not always expeditious when it comes to unifying national legal rules with international law (Júdová, 2009). Indeed, cultural prejudices constrain the universal acceptance of certain rights, not to mention international pressure and their enforcement.

Thirdly, the financial burden of the World Court is another issue in dispute. The financial compensation for the victims of human rights abuses in Europe climb each year to millions of euro. ${ }^{31}$ As there are already doubts about the number of the States parties and other actors supporting the idea of the creation of the World Court, an additional question arises as to whether such a Court will have sufficient resources to provide for effective pursuit. The parties to the Statute would be accordingly the contributors to the Court's Fund. Hence, without the endorsement of financially strong and stable states, the capacity of the Court will be threatened. The US has already expressed its opinion on similar institutions; China, Russia, and the majority of the Islamic states are not among the most passionate defenders of human rights, despite their declared will to follow these standards. ${ }^{32}$ Compliance from the European States might be jeopardized by the argument that there is a sufficiently developed and well-functioning human rights system inside the European Union and no

\footnotetext{
28 'American Foreign Policy and the International Criminal Court' Retrieved May 8, 2016, from http://www.coalitionfortheicc.org/documents/USUnsigningGrossman6May02.pdf.

${ }^{29}$ Ibid.

${ }^{30}$ Equality Act 2010.

${ }^{31}$ Ibid (n23).

${ }^{32}$ Cairo Declaration on Human Rights in Islam 1990; Bangkok Declaration on Human Rights 1993.
} 
need for the establishment of the World Court (Treschel, 2004). Nevertheless, a gesture of contribution from those States lacking the resources and will to strengthen the legitimacy of human rights within their own domestic system is also more than unexpected.

Fourthly, as the essential merits of the establishment of the World Court are presumed to be the functional enforcement mechanism, supervision over the execution of the judgements and provision of remedies for victims of human rights abuses, these are most likely to cause the ultimate problems. The work of the Human Rights Council is already largely criticised (Ahrens, 2010) and as a supervisory body might represent an intrinsic 'danger of the politicisation and the undermining of the Court's judgements' (Ulfstein, 2008). Analogy to the European model in the supervision of execution of judgements could raise concerns about the length of processes and the further length of the implementation or the change of domestic legislation. In the Marckx v. Belgium ${ }^{33}$ case, it took Belgium more than ten years to comply with international rules. ${ }^{34}$ There are situations where the constant breach of human rights is a matter of an unstable political environment leading to deadlocks in peace, security and the accomplishment of human rights standards. ${ }^{35} \mathrm{~A}$ crucial element of the judicial body is credibility and honoured judgements. It is therefore to be considered whether the focus and the resources of international community should not be directed towards the support of national judicial systems rather than risk the incapacity of a new one. ${ }^{36}$

Justifications against the establishment of the World Court are predominantly dependent on the attitude of state parties and other actors towards the contemporary framework of human rights. Assumptions about their willingness and support must be drawn upon their previous reactions to new international judicial organs, on the structural development of the International Conventions and related UN treaty-based bodies. The high number of reservations by signatory states, but also the ultimate antipathy to comply with the human rights rules might incite presumptions of general antagonism of the World Court of Human Rights.

\section{Conclusion}

For almost seven decades, there was an idea to build a system of protection and promotion of human rights for every person in the world, no matter differences in nation, culture, traditions, race, religions, or beliefs. The international community has been developing a concept that imposed new movements in the perception of human existence and the relationship between the state and the individuals. This idea became the inheritance of the next generation, whose consistent work led to the system of human rights law. It provides people with the protection and guarantees through the international organs and bodies and regional systems. Most importantly, the international initiatives have achieved almost universal acceptance and the enforcement of human rights law at the state level, which

\footnotetext{
33 [1979] 2 EHRR 330.

${ }^{34}$ The case dealt with unsatisfactory legal conditions for children born out of wedlock, changed by an Act of 31 March 1987.

${ }^{35} \mathrm{~A} / \mathrm{HRC} / \mathrm{S}-16 / 1$ (2011).

36 'Strengthening of the United Nations: an agenda for further change' A/58/351 p5.
} 
is, due to the true disparity between the nations, a distinct success. The idea of the World Court of Human Rights has remained unaccomplished because of the high number of challenges that needed to be bridged in the past. However, the current framework is still the subject of improvements; the gaps in their function merely arise from the absence of one permanent and honoured institution capable of giving the united procedural ground and the international legal force to the findings of the abuses of human rights. The World Court would strengthen compliance with human rights law; it would enhance the awareness of people by giving a clear and unified way to protect individual rights. It will increase the efficiency and the credit of contemporary system and nevertheless, contribute to the further substantial development of international human rights law. The cooperation of the international community in order to establish the World Court of Human Rights would finally represent the major step forward in accomplishing the undeniable effort and outstanding work of the previous generations of unbelievably brave and honoured "idealists".

\section{References}

Ahrens, L. (2010). RNW. Retrieved May 8, 2016, from http://www.rnw.nl/internationaljustice/article/un-human-rights-council-faces-same-criticism-its-predecessor.

Bayefsky, A. F. (1996). UN Human Rights Treaties: Facing the Implementation Crisis. Windsor Y.B. AccessJust, 15, 189.

Cassel, D. (2001). Does International Human Rights Law Make a Difference? Chi.J. Int'l. $L, 2,121-135$.

Cassese, A. (2008). The Oxford Companion to International Criminal Law (2nd ed.) Oxford: OUP.

Donnelly, J. (2007). The Relative Universality of Human Rights. HRQ, 29, 281-306.

Edelenbos, C. (1994). Human Rights Violations: A Duty to Prosecute? Leiden J. Int'l. L, 7(2), 5-21.

Goldston, J. A. (2011). From Judgment to Justice - Implementing the Views of the United Nations Human Rights Committee Open Society Foundation Retrieved May 5, 2016, from https://www.opensocietyfoundations.org/sites/default/files/goldston-hrc-20110330.pdf.

Holubová, M. (2011). Stredoeurópska kultúrna platforma a spoločenské podujatia v rámci krajín V4. Cezhraničná spolupráca štátov V4: medzinárodná vedecká konferencia, Sládkovičovo: Vysoká škola Visegrádu s r.o., Vysoká škola v Sládkovičove, 128-144.

Hudson, M. O. (1933). A Permanent Court of Arbitration. AJIL, 27(3), 440-460.

Júdová, E. (2009). Význam ludských práv v medzinárodnom práve súkromnom zjednotenej Európy. In.: ed. Lantajová, D.: Úloha medzinárodného práva a európskeho práva v 21. storočí z pohladu krajín V4. Trnava: Trnavská univerzita v Trnave Právnická fakulta, $1-11$.

Mubangizi, J. C. (2006). Some reflections on recent and current trends in the promotion and protection of human rights in Africa: The pains and the gains. Afr.HRts. L. J., 6(1), 146-165.

Nowak, M. (2007). The Need for a World Court of Human Rights. HRLR., 7, 251-259. 
Nowak, M. (2009). Eight Reasons why we need a World Court of Human Rights. In Alfredsson, G. et al. (2009). International human rights monitoring mechanisms: essays in honour of Jakob TH. Möller (2nd edition). Boston: Leiden.

Nowak, M., Kozma, J. (2009). A World Court of Human Rights. Retrieved May 1, 2016, from https://www.eui.eu/Documents/DepartmentsCentres/AcademyofEuropeanLaw/CourseMaterialsHR/HR2009/Scheinin/ScheininClassReading2.pdf.

O'Boyle, M. (2008). On reforming the Operation of the European Court of Human Rights. EJHRL, 1(1), 3.

O’Flaherty, M., O’Brien, C. (2007). Reform of UN Human Rights Treaty Monitoring Bodies: A Critique of the Concept Paper on the High Commissioner's Proposal for a Unified Standing Treaty Body. HRLR, 7(1), 141-172.

Open Society Justice Initiative /Brookings Institution's Foreign Policy program/ UPRWatch (2010 Report of Proceedings Improving Implementation and Follow-up Treaty Bodies, Special Procedures, Universal Periodic Review. Retrieved May 1, 2016, from https://www.opensocietyfoundations.org/sites/default/files/improving-implementation-20110307.pdf.

Rescia, V. R., Seitles, M. D. (1999-2000). The Development of the Inter-American Human Rights System: A Historical Perspective and a Modern-Day Critique. N.Y.L. Sch.JHR, 16, 593-959.

Roht-Arriaza, N. (1995). Impunity and Human Rights in International Law and Practice. Oxford: OUP.

Scheinin, M. (2009). Towards a World Court of Human Rights' European University Institute. Retrieved May 1, 2016, from http://www.udhr60.ch/report/hrCourt_scheinin0609.pdf. Steiner, H. J. et al. (2007). International Human Rigths in Contex: Law, Politics and Morals. Oxford: OUP.

Tomuschat, Ch. (2003). Human Rights: Between Idealism and Realism. Oxford: OUP. Treschel, S. (2004). A World Court for Human Rights? NW. J.Int'l. HR, 1, 11.

United Nations Watch (2008). Eleanor's Dream 1948 to 2008: The State of Human Rights at the United Nations. Scorecard and Report on the UN Human Rights Council. Retrieved May 1, 2016, from https://www.scribd.com/document/22193732/Eleanors-Dream-TheState-of-Human-Rights-at-the-United-Nations-1948-to-2008.

Ulfstein, G. (2008). Do We Need a World Court of Human Rights? In Engdahl, O., Wrange, P. (2008). Law at war: the law as it was and the law as it should be. Martinus Nijhoff. Ušiak J., Saktorová L. (2014). The International Court of Justice and The Legality of UN Security Council Resolutions. DANUBE: Law and Economics Review, 5(3), 201-212. Wachira, G. M. (2008). African Court on Human and People's Rights: Ten years on and still no justice. Retrieved May 1, 2016, from http://minorityrights.org/wp-content/uploads/oldsite-downloads/download-540-African-Court-on-Human-and-Peoples-Rights-Ten-years-on-and-still-no-justice.pdf. 